Folia Oeconomica Stetinensia

DOI: 10.2478/v10031-009-0027-1

Wydział Nauk Ekonomicznych i Zarządzania

Uniwersytetu Szczecińskiego

\title{
CORPORATE MODEL OF THE ALGERIAN NATIONAL MARBLE COMPANY
}

\author{
Fatima Nibouche, Ph.D. student \\ Industrial Engineering Department \\ National Polytechnic School \\ 10, avenue Hassan Badi, El-Harrach, Algiers (21000), Algeria \\ e-mail:fnibouche@yahoo.com
}

Oumhani Belmokhtar, Prof.

Industrial Engineering Department, National Polytechnic School, 10, avenue Hassan Badi, El-Harrach, Algiers (21000), Algeria

E-mail: oumh_bel@yahoo.fr

Received 24 January 2009, Accepted 9 July 2009

\begin{abstract}
In today's dynamic and competitive environment, planning for effective use of the company resources requires an analytical and integrated approach of its essential functions. With such goal in mind, the corporate planning model, in which the modules of production and marketing are related to the financial module, presents a very efficient solution. It is particularly well suited for the needs of Algerian companies operating in an environment that has undergone a transformation from planned economy to market economy where risks and uncertainties are ubiquitous. Furthermore, Algerian companies should take account of the importance of strategic planning and forecasting where, in that context, the corporate planning model provides a powerful tool for decision-making. This work provides a corporate planning model specified for the Algerian National Marble Company. The presented model has been devised and validated from the company data to generate physical and financial short-term forecasts. The obtained empirical results show the usefulness of such a model for the managers in terms of providing a precise model of the essential functions of the company, helping to evaluate the consequences of different management scenarios and assisting in the decision-making process. Furthermore, using prospective simulations, the presented model can be used as a tool for forecasting.
\end{abstract}

Keywords: integrated model, functions of business, forecasting, sensitivity analysis.

JEL classification: C39, C51, G12. 
Acknowledgements: The authors gratefully acknowledge the generous participation of senior executives from the Algerian national marble company which allowed this case to be developed.

\section{Introduction}

In a dynamic environment which is characterised by an ever-growing competitiveness and a continuous state of flux, planning the effective use of existing and future resources of a company requires without any doubt a very careful attention. Find tools able to take account of key data of the company and to meet the expectations of managers seems crucial. The interdependences of the different functions of the company do not make this an easy task. In addition, Algerian companies living in a changing economic environment, marked by a market in growing complexity, should give more importance to aspects of modelling and planning in order to understand their systems, to optimize the use of resources and to achieve positive results.

An analytical approach appeared in the early 70's and which identifies the dynamics of the company on one side and the financial aspects on the other, taking into account the interrelationships that exist between the essential functions of the company, is a very useful tool in this regard ${ }^{1}$. The corporate planning modelling is a systemic approach that incorporates production and marketing modules to the financial module. The resulting model allows the manager to have an overall view of the business and facilitates the evaluation of managerial strategies, hence decision-making. Thus, the obtained module can be improved and refined until it meets the expectations of the manager. Over the years, such approach has proven to be practical, useful and credible as it has come to grasp the complex problems faced by companies and evaluate strategies developed by the managers ${ }^{2}$.

The model summarized in this study is a corporate planning model simulated from the Algerian national marble company data. This is a model that incorporates some physical and financial aspects of the business and some financial ratios including the production in quantity, the labour expressed in number of workers, the incomes of the products of the company, the stocks in value, the permanent capital, the capital working evolution in the value added and the debt ratio.

The first aim of the elaborate model is to assist managers in acquiring a better understanding of the behaviour of the company by gaining more knowledge about the interrelationships between the key variables and the exogenous variables explaining them. In this way the 
model becomes a learning process for the managerial staff to acquire understanding of the business.

The second aim is to analyse different scenarios that can affect the good functioning of the organization. As such, it is a powerful tool to assist in the decision-making process. The third goal is to use the model in performing short term forecasts on the key variables and to test the sensitivity analysis, which tends to respond to questions such as "what if?" Thus, the built model can be expanded by the integration of new models with key variables which have not been included in the present model.

This model is composed of three blocks. The first block includes linear equations and constitutes a system of simultaneous equations developed empirically from annual data from the company between 1994 and 2005. The second block is made up of accounting identities with a few key variables of the company while the third block includes financial ratios essential for good management. The values obtained for these ratios are determined by the principle of recursion. The model thus established traces the evolution of economic variables modelled during the period 1994-2005. It is used in the preparation of forecasts for the period 2006 to 2010 and in testing sensitivity analysis.

The paper is divided into three sections. The first section provides an overview of the corporate planning approach, its definitions and its history while the second section presents the corporate planning model developed for the Algerian national marble company and tests its validity. The third section presents the prediction part and the forth one concerns the validation of the built model.

\section{Definitions, Uses and History of Corporate Modelling}

The corporate planning model has since its appearance been widely used. The growing availability of computers has encouraged even small and medium enterprises to model their functions of production, marketing and even their financial activities and thus form global models of their companies to facilitate the development of strategies and decision-making ${ }^{3}$.

\subsection{Definition and Uses}

The definition of a corporate planning model varies with the scope of its application. For instance, financial planning models may have a very short planning-horizon and entail no more than a collection of accounting formulae for producing pro forma statements ${ }^{4}$. The cor- 
porate planning model is considered as an attempt to model the behavior of an entire corporation $^{5}$. With the corporate planning model the firm's distribution, finance, production, information and control subsystems are treated as though they were completely interdependent (see Figure 1).

In a similar way, the corporate planning models are identified as sets of related expressions that represent the key operations of the companies ${ }^{6}$. They may vary in sophistication, size, range of applications, and so forth. However, in their most common form, the model comprises little more than accounting statements linked in a straight-forward way.

The corporate planning models are considered a separate class of models in which the quantitative and logical inter-relationships among a corporation's financial, marketing and production activities are simulated. As such, the models have greater utility as the isolation of an equation or a set of equations of the models for a specific or restricted application is possible ${ }^{7}$. Furthermore, the addition of new modules in order to refine the models is accepted as well. Therefore, the corporate planning models are open systems which can be improved continuously.

Planning models can be categorized according to two approaches: simulation and optimization $^{8}$. Simulation models are attempts to represent mathematically the operations of the company or of the conditions in the external economic environment. The probabilistic simulation models incorporate probability estimates into the forecast sequence, while deterministic simulation models do not. Optimization models are intended to identify the best decision, given specific constraints.

Typically, a corporate planning model can be used ${ }^{9}$ to:

- Simulate an alternative strategy by evaluating its impact on profits;

- Help establish corporate and divisions goals;

- Measure the interactive effect on segments within the firm;

- Help management better understand the business and its functional relationship and help improve decision-making ability;

- Assess critically the assumptions underlying environmental constraints;

- Link the firm's goals and strategies to its master budgets. 


\subsection{History of Models}

In the early 1960 s the rudiments of corporate modelling were placed with the large cumbersome simulation models developed by major corporations. The efforts were multiplied for the development of large and sophisticated models.

The originality of these models lain on their complexity. Indeed, they were made up in the vast majority of hundreds of equations and demanded a great deal of data. They were bulky models par excellence. However, they allowed the managers to test the alternatives analysis and to reduce the time.

In terms of complexity, Mattessich ${ }^{10}$ has built one of the most advanced models in the early 1960s. This was a deterministic model describing the company in terms of conventional accounting identities. The GPE simulation $\operatorname{model}^{11}$ was one of the first corporate planning models to use the simulation in the field of finance. It was a simulation model of the investment decisions of a Trust Officer in a bank. Other notable examples were the Hillier model ${ }^{12}$ which evaluated risk of investment decisions, and Hertz mode ${ }^{13}$ which suggested corporate planning approaches to assist investment decisions under risk.

Shortly thereafter, Gershefski ${ }^{14}$ presented the largest and the most complex model developed during that period; the corporate planning model of the Sun Oil Company. This model was used to prepare short-term profits and long-term forecasts and to solve specific problems in management.

Among many other models that have appeared during this period, we can list the most important, the Boise cascade Pacific Northwest investment planning model ${ }^{15}$ simulated the effects of timber land purchases and capital expenditures on profit. The Xerox model ${ }^{16}$ tested the feasibility of strategies; evaluated financial effects of them and measured impacts of new proposals. The IBM model ${ }^{17}$ calculated the balance sheets, the income statements and statements of sources and uses of funds for each year. In addition, the model provided measurements of corporate performance. The Dow Chemical corporate mode ${ }^{18}$ was a deterministic accounting simulation model. The Pillsbury expenditure model ${ }^{19}$ a time-sharing model used in the analysis of the proposed business acquisitions.

A great enthusiasm accompanied this time and led to the multiplication of complex models. However, the economic crises in 1974-75 and again in 1979-80 plans emphasised the vagueness of gigantic models. That is why the eighties witnessed the proliferation of integrated corporate planning model less complex. Also, new approaches emerged and were used 
in the development of corporate planning model. We can note the dynamic systems, the neural networks and the chaos theory ${ }^{20}$.

Kivijärvi and Tuominen ${ }^{21}$ presented a study in which the synergetic effects of production financial and marketing planning are of interest. It is shown how a corporate model can effectively serve as a tool in the process of integrating and coordinating production, financial and marketing plans. The outputs of the corporate model were combined with a hierarchical evaluation procedure in order to have congruent objectives.

Lotz and Yen ${ }^{22}$ presented a Telecommunications Strategic Planning Model as a tool that management can use to deploy telecommunications as a competitive weapon. The model's strength is its ability to assist an organization in finding opportunities.

Kirca and Koksalan ${ }^{23}$ presented an integrated production and financial planning model for a domestic company operating in an environment of high inflation rates in a developing country. Kivijärvi and Tuominen ${ }^{24}$ developed a dynamic corporate planning model for a company associated with a wood-assessment procedure.

Today, more and more companies are using, developing or experimenting some forms of corporate planning model. This is essentially due to the development of software for planning and modelling that make models easier to develop without a great knowledge of programming languages ${ }^{25}$.

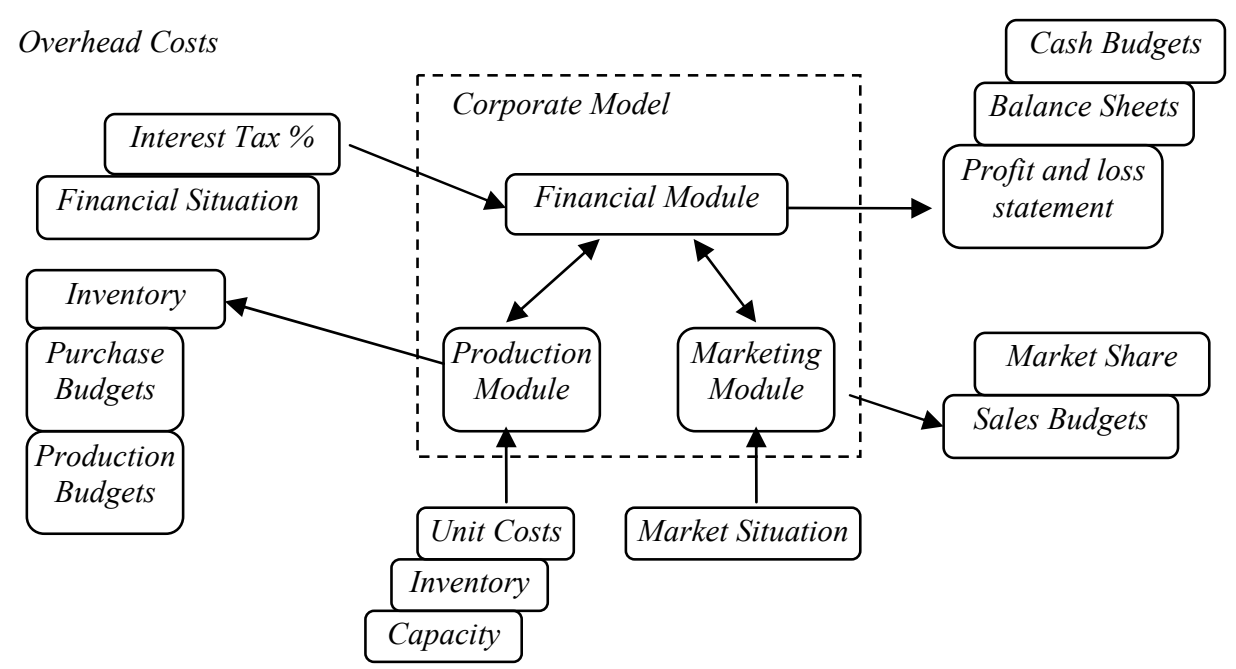

Fig. 1. Typical Structure of a Corporate Model

Source: Kivijarvi, Tuominen, 1987. 
Among the new developments in integrated planning models, we can cite the model developed by Mohamed ${ }^{26}$. That is an integrated production and distribution model for a multinational company operating in an environment of changing exchange rates.

The results from the model yield some significant insights into the planning of multinational companies. In addition, Tarrazo and Gutierrez ${ }^{27}$ propose the fuzzy sets based on quantitative methodologies as methodologies capable of integrating the uncertainty in this type of model. Bhutta, Huq, Frazier and Mohamed ${ }^{28}$ present a mixed integer linear model for a multinational corporation. That model integrates production, distribution and investment. More recently, Mulvey and Shetty ${ }^{29}$ present a general framework for such models using multi-stage stochastic programming.

The presented model in this paper is a simulation model which integrates the production, financial, marketing functions of the Algerian national marble company. The outputs of the model are forecasts of physical quantities produced and sold of the different products of the corporation, the labour expressed by the number of workers used for every product. The financial outputs include the income of the sale of the products, the working capital and the permanent capital among other important financial aggregates. The financial ratios that are very important for the corporation are obtained by the principle of recursion. They count ratios as debt and investment rates. The sensitivity analysis will enable the manager to explore many scenarios in order to test the stability of the model and to measure the effects of change in key variables.

\section{Corporate Planning Model for the Algerian National Marble Company}

Although new approaches in the development of corporate planning models have emerged and are used in the modelling, we have opted for a classic approach in order to enable managers to understand the model to use and to perfect it. The model presented below is a simulation model that models the internal dynamics and the financial function of the Algerian national marble company to generate physical and financial forecasts. These outputs include quantities produced and the quantities sold of the different products of the corporation, the labour expressed by the number of workers used for every product, the income of the different products, the working capital and the investment rate.

Such model links the production and marketing functions with the financial function. It traces the evolution of the key variables describing these functions, taking into account the interrelations between them. This model involves simultaneous equations, financial identities 
and financial ratios. It will be used in the short-term forecasting and sensitivity analysis such as "What if?" The software used in the calculations is a statistical and econometric software package called EVIEWS 3.1.

This section is structured as follows: in 3.1 the environment operated in and the problem definition are precised, in 3.2 the theoretical equations of the model are presented. In 3.3 the nature of the data used is specified. In 3.4 the model is estimated while in 3.5 the variables used are reviewed. In 3.6 the model is simulated and finally in 3.7 , the validity of the model is tested.

\subsection{Environment Operated in and Problem Definition}

The marble is used as building o decoration material in the manufacture of artefacts. Algeria has many deposits of natural decorative stones which only a dozen are operated open air in the north. The two largest marble basins in Algeria are those of Fil-Fila in the east of the country, $500 \mathrm{~km}$ from Algiers and Krystel in the west of the country $400 \mathrm{~km}$ from Algiers. Since the abolition of the state monopoly on this activity in 1991 and the promulgation of the new mining law in July 2001 which offers many fiscal and parafiscal advantages, the marble activity in Algeria has been freely open to any national or foreign investor. At the moment, the marble industry in Algeria, in this phase of profound changes of the Algerian economy, has many development opportunities thanks to three key factors: the existence of large deposits of marble, a carrying market and a long tradition of marble and ornamental stone.

The company under consideration is the Algerian national marble company. This company has been established on 16 July 1983, continued to the national society in mining research and exploitation restructuring in 1983. It has become a shareholding company in March 1991. For several years this company has built a solid experience and expertise in the field of mining and processing of natural marble. Its main activities are Operation career for the extraction of marble blocks, transformation of blocks in various products, production of a variety of ornaments in marble, exploitation of quarries for the production of derivatives marble and sales of all products on domestic and foreign markets. Its products are marble blocks, slabs, tiles, marble derivatives and quarries aggregates. At first, the company had a monopoly on the market for derivative marble in Algeria. This monopoly has deeply marked the posture of the industrial company and its management culture especially in the commercial field. Indeed the company is as far as now in logic of production, not sales. Today, next to this company operate many private marble active in the transformation of marble slabs and tiles. The 
medium-term development axes for that corporation are: rehabilitation and optimization of the potential that exists, intensive development of marble quarries and export development.

The model proposed in this paper is intended as an analytical tool that can be used for the short term planning in the Algerian national marble company. Its aim is to model the behaviour of the company in production, finance and marketing in an integrated model that respects the interrelationships of those functions.

The model consists in three blocks. Every block includes a set of equations. The first block is a system of simultaneous equations expressing for the corporation products the quantities produced, the quantities sold and the labour used. The second block is a set of financial identities concerning the balance sheet. It includes the incomes, the debts, the added value and the investments. The third block is composed of financial ratios including debt ratio and the evolution in added value. The outputs of the model are physical and financial short term forecasts. This model will permit to the managers to have an overview on the business and to learn more about its behaviour. It will also help in the evaluation of different scenarios and in the sensitivity analysis.

\subsection{Theoretical Equations of the Model}

A first step before modelling consists of the analysis of the business functions and the interrelationships that exist between them. The interrelationships may be expressed in diagram form to allow exploration of the relationships and the identification of dependencies ${ }^{30}$. This study of flow has led to consider some key variables. These key variables number physical and financial variables. They include the quantities produced, the quantities sold, the labour which is assimilated to the number of workers employed, the incomes and the added value ratio. The developed model is composed of three blocks. The equations of the first block are behavioural ones. They will be tested empirically. These equations are as follows:

\section{Quantities produced}

There is a need to incorporate the internal dynamics of the firm (Kaye, 1994). These are primarily represented by the production function, which seeks to express the relationships between inputs and outputs. The quantities produced of each product are explained by the labour expressed in number of workers, the capacity of the machines used in the production process and a random error term:

Quantities produced $=\mathrm{f}($ Labour, Capacity Used of the machines $)+$ random error. 


\section{Quantities sold}

The quantity sold of each product is explained by the price, the orders and the quantity produced. The corporation gives no importance to the marketing. It is in logic of production not sale. As a consequence, the relative variables to the market as the competition are not represented in the quantities sold equations:

Quantities sold $=\mathrm{f}($ Production, Price, Orders $)+$ random error .

\section{Labour}

The labour used by product is largely explained by the unit labour cost and the quantity produced by product. This labour is expressed in numbers of workers:

Labour per product $=\mathrm{f}($ Production per product, Unit labour cost $)+$ random error.

\section{Total Labour}

The total labour used in the production is the sum of the labours used for the different products:

$$
\text { Total Labour }=\text { Sum of Labour per product. }
$$

The second block includes financial identities. This block concerns the incomes, the permanent capital, the working capital, the investments and the debts among other aggregates very important for the manager. The third block includes financial ratios. These ratios concern the evolution in the value added the debt ratio and other important ratios for the corporation.

\subsection{The Data}

The data used are taken from the annual management reports of the Algerian national marble company and cover the period from 1994 to 2005. They include physical and financial data. The unit of currency used is the thousands of Algerian dinars. The units used for the quantities produced and the quantities sold of the blocks of marble and the aggregates of quarries, the slabs and the tiles and finally the derivatives of marble are respectively: the cubic meter $\left(\mathrm{m}^{3}\right)$, the square meter $\left(\mathrm{m}^{2}\right)$ and the tonne $(\mathrm{t})$.

\subsection{Model Estimation}

The model is composed of three blocks. Only the first block will be estimated. The second block includes financial identities while the third block is made of financial ratios. The elaborate model is composed of three blocks as follows: 
Block1: The first block is a system of simultaneous equations. The linear equations of this system are estimated by the method of the two stage least squares. The coefficient of determination is given for each equation of the first block:
1) $\mathrm{Q}_{1}=13091.7670 \mathrm{CU}_{1}+14028.9500 \mathrm{CU}_{1}(-1)+13.8476 \mathrm{EFF}_{1}$
$\left(\mathrm{R}^{2}=0.96\right)$
2) $\mathrm{Q}_{2}=940.3078 \mathrm{EFF}_{2}-630.1944 \mathrm{EFF}_{2}(-1)+240294.3800 \mathrm{CU}_{2}+[\mathrm{AR}(3)=-1.1107]$
$\left(\mathrm{R}^{2}=0.96\right)$
3) $\mathrm{Q}_{3}=1994.3690 \mathrm{EFF}_{3}-1575.5287 \mathrm{EFF}_{3}(-1)+0.4317 \mathrm{Q}_{3}(-2)+[\mathrm{AR}(2)=-0.6564]$
$\left(\mathrm{R}^{2}=0.97\right)$
4) $\mathrm{Q}_{4}=96.9694 \mathrm{EFF}_{4}+0.9812 \mathrm{Q}_{4}(-1)-0.2670 \mathrm{Q}_{4}(-3)$
$\left(\mathrm{R}^{2}=0.98\right)$
5) $\mathrm{EFF}_{1}=-1.6633 \mathrm{CW}+1.6267 \mathrm{CW}(-1)+1.0185 \mathrm{EFF}_{1}(-1)$
$\left(\mathrm{R}^{2}=0.98\right)$
6) $\mathrm{EFF}_{2}=-0.8552 \mathrm{CW}+0.002 \mathrm{Q}_{2}+77.9791$
$\left(\mathrm{R}^{2}=0.98\right)$
7) $\mathrm{EFF}_{3}=-0.0518 \mathrm{CW}+0.003 \mathrm{Q}_{3}(-1)+0.1947 \mathrm{EFF}_{3}(-2)+98.1662$
$\left(\mathrm{R}^{2}=0.98\right)$
8) $\mathrm{EFF}_{4}=-0.0271 \mathrm{CW}+0.9826 \mathrm{EFF}_{4}(-1)$
$\left(R^{2}=0.98\right)$
9) $\mathrm{Labour}=\mathrm{EFF}_{1}+\mathrm{EFF}_{2}+\mathrm{EFF}_{3}+\mathrm{EFF}_{4}$
10) $\mathrm{QV}_{1}=0.0405 \mathrm{Q}_{1}-0.5877 \mathrm{QV}_{1}(-2)-0.4580 \mathrm{QV}_{1}(-3)-66.0060 \mathrm{P}_{1}+0.2040 \mathrm{D}_{1}+7168.9866$
$+[\operatorname{AR}(1)=-1.5993, \operatorname{AR}(2)=-1.3011]$
$\left(\mathrm{R}^{2}=0.99\right)$
11) $\mathrm{QV}_{2}=0.3678 \mathrm{Q}_{2}+0.3422 \mathrm{QV}_{2}(-1)+0.1601 \mathrm{D}_{2}-135450.2300 \mathrm{P}_{2}+142889.6100 \mathrm{P}_{2}(-1)$
$+[\operatorname{AR}(1)=-0.9486, \operatorname{AR}(2)=-0.6907]$
$\left(\mathrm{R}^{2}=0.99\right)$
12) $\mathrm{QV}_{3}=0.9971 \mathrm{Q}_{3}-4476.4081 \mathrm{P}_{3}-0.0491 \mathrm{QV}_{3}(-2)+7881.2408+[\mathrm{AR}(4)=-0.7839]$
$\left(\mathrm{R}^{2}=0.99\right)$
13) $\mathrm{QV}_{4}=1.0854 \mathrm{Q}_{4}-0.7801 \mathrm{Q}_{4}(-2)+0.7274 \mathrm{QV}_{4}(-2)$
$\left(\mathrm{R}^{2}=0.99\right)$

The equations of the first block seem to be acceptable. The statistical coefficients obtained for each equation are good (see the annexes (Table A1 to Table A12) for some statistical coefficients).

Block 2: The second block is made up of financial identities. They concern in their majority the balance sheet of the company and are as follows:

\begin{tabular}{|l|l|}
\hline 1) $\mathrm{RR}_{1}=\mathrm{QV}_{1} \mathrm{P}_{1}$ & 10) $\mathrm{DTT}=\mathrm{DCT}+\mathrm{DLM}$ \\
2) $\mathrm{RR}_{2}=\mathrm{QV}_{2} \mathrm{P}_{2}$ & 11) $\mathrm{BFR}=\mathrm{STK}+\mathrm{CRCC}-\mathrm{DCT}$ \\
3) $\mathrm{RR}_{3}=\mathrm{QV}_{3} \mathrm{P}_{3}$ & 12) $\mathrm{CRC}=\mathrm{CRCC}+\mathrm{CRLT}$ \\
4) $\mathrm{RR}_{4}=\mathrm{QV}_{4} \mathrm{P}_{4}$ & 13) $\mathrm{QE}=\mathrm{RR}-\mathrm{VMA}+\mathrm{QS}+\mathrm{QI}$ \\
5) $\mathrm{RR}=\mathrm{RR}_{1}+\mathrm{RR}_{2}+\mathrm{RR}_{3}+\mathrm{RR}_{4}+\mathrm{BB}$ & 14) $\mathrm{VA}=\mathrm{QE}+\mathrm{MGB}-\mathrm{CINT}$ \\
6) $\mathrm{STK}=\mathrm{STK}(-1)+\mathrm{DSTK}$ & 15) $\mathrm{RNE}=\mathrm{RR}-\mathrm{charges}$ \\
7) $\mathrm{KPE}=\mathrm{KPR}+\mathrm{DLM}$ & 16) $\mathrm{PASSIFN}=\mathrm{KPR}+\mathrm{DTT}+\mathrm{RNE}+\mathrm{IB}$ \\
8) $\mathrm{FR}=\mathrm{KPR}+\mathrm{DLM}-\mathrm{ACTI}$ & 17) $\mathrm{ACTIFN}=\mathrm{INVEST}+\mathrm{STK}+\mathrm{CRC}$ \\
9) $\mathrm{TR}=\mathrm{FR}-\mathrm{BFR}$ & 18) INVEST $=\mathrm{INVEST}(-1)+\mathrm{DINVEST}$ \\
\hline
\end{tabular}


Block 3: The third block is composed of some financial ratios as follows:

\begin{tabular}{|l|l|}
\hline 1) $\mathrm{S}_{1}=(\mathrm{VAF}-\mathrm{VAF}(-1)) / \mathrm{VAF}(-1)$ & 6) $\mathrm{S}_{6}=\mathrm{KPRF} / \mathrm{PASSIFNF}$ \\
2) $\mathrm{S}_{2}=(\mathrm{FRF} / \mathrm{STKF}) \cdot 100$ & 7) $\mathrm{S}_{7}=\mathrm{DTTF} / \mathrm{PASSIFNF}$ \\
3) $\mathrm{S}_{3}=\mathrm{RNEF} / \mathrm{RRF}$ & 8) $\mathrm{S}_{8}=\mathrm{KPEF} / \mathrm{DTTF}$ \\
4) $\mathrm{S}_{4}=(\mathrm{TRF} / \mathrm{RRF}) \cdot 100$ & 9) $\mathrm{S}_{9}=\mathrm{INVESTF} / \mathrm{ACTIFNF}$ \\
5) $\mathrm{S}_{5}=\mathrm{DTTF} / \mathrm{RRF}$ & 10) $\mathrm{S}_{10}=\mathrm{STKF} / \mathrm{ACTIFNF}$ \\
\hline
\end{tabular}

The values of these financial ratios are obtained by the principle of recursion. Indeed, each equation of the third block is solved one at a time by substituting the solution values of the preceding equations of the second block.

\subsection{The Variables of the Model}

The endogenous variables selected for the model are:

\begin{tabular}{|c|c|}
\hline $\begin{array}{l}\mathbf{Q}_{1} \text { : Quantities Produced of marble blocks } \\
\mathbf{Q}_{2} \text { : Quantities Produced of slabs and tiles } \\
\mathbf{Q}_{3} \text { : Quantities produced of marble derivatives } \\
\mathbf{Q}_{4} \text { : Quantities produced of quarries aggregates } \\
\mathbf{E F F}_{1} \text { : Labour used in the production of marble blocks } \\
\mathbf{E F F}_{2} \text { : Labour used in the production of slabs and tiles } \\
\mathbf{E F F}_{3} \text { : Labour used in the production of marble deriva- } \\
\text { tives } \\
\mathbf{E F F}_{4} \text { : Labour used in the production of quarries aggre- } \\
\text { gates }_{\mathbf{Q V}_{\mathbf{1}} \text { : Quantities sold of marble blocks }} \\
\mathbf{Q V}_{2} \text { : Quantities sold of slabs and tiles } \\
\mathbf{Q V}_{3} \text { : Quantities sold of marble derivatives } \\
\mathbf{Q V}_{4} \text { : Quantities sold of quarries aggregates } \\
\mathbf{L a b o u r}_{\text {: }} \text { Total labour used }\end{array}$ & $\begin{array}{l}\text { RR }_{\mathbf{3}} \text { : Income of the sale of marble derivatives } \\
\text { RR }_{\mathbf{4}} \text { : Income of the sale of quarries aggre- } \\
\text { gates } \\
\text { RR: Total Income } \\
\text { STK: Stocks } \\
\text { KPE: Permanent capital } \\
\text { FR: Working capital } \\
\text { TR: Cash } \\
\text { DTT: Debts } \\
\text { BFR: Working capital requirement } \\
\text { CRC: Receivables } \\
\text { QE: Annual production in value } \\
\text { VA: Added value } \\
\text { RNE: Net operating } \\
\text { PASSIFN: Net liability } \\
\text { ACTIFN: Net Assets } \\
\text { INVEST: Investment }\end{array}$ \\
\hline
\end{tabular}

The exogenous variables included in the explanation of the previous endogenous variables are: 


\begin{tabular}{|c|c|}
\hline $\mathbf{C U}_{1}$ : Capacity used in the production of marble & BB: Other items sold \\
\hline blocks & DLM: Long and medium term debts \\
\hline $\mathbf{C} \mathbf{U}_{2}$ : Capacity used in the production of slabs & DINVEST: Change in investment \\
\hline and tiles & DCT: Short-term debts \\
\hline CW: Unit labour cost & ACTI: Fixed assets \\
\hline $\mathbf{P}_{1}$ : Unit sale price of marble blocks & Charges: Total charges \\
\hline $\mathbf{P}_{2}$ : Unit sale price of slabs and tiles & CRLT: Long-term claims \\
\hline $\mathbf{P}_{3}:$ Unit sale price of marble derivatives & CRCC: Short-term claims \\
\hline $\mathbf{P}_{4}:$ Unit sale price of quarries aggregates & QS: Stored production \\
\hline $\mathbf{D}_{1}$ : Orders for marble blocks & QI: Invested production \\
\hline $\mathbf{D}_{2}:$ Orders for slabs and tiles & VMA: Revenue from sales of goods \\
\hline \multirow[t]{4}{*}{ KPR: Equity } & MGB: Gross margin \\
\hline & CINT: Intermediate consumption \\
\hline & DSTK: Change in stocks \\
\hline & IB: Income taxes \\
\hline
\end{tabular}

The variables of the third block obtained by the principle of recursion take an $\mathrm{F}$ at the end. They are noted: VAF, RRF, RNEF, FRF, STKF, KPEF, KPRF TRF, DTTF, INVESTF, PASSIFNF and ACTIFNF.

\subsection{Simulation Model}

Once estimated, the model is subject to simulations. After nine iterations, the convergence is obtained. The Figures 1-3 are obtained for some variables of the first block.

Fig. 1. Quantities produced of marble blocks

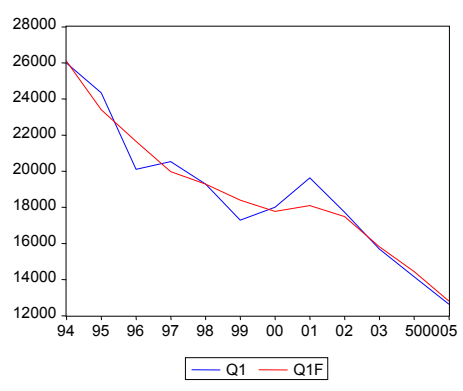

Fig. 2. Quantities produced of slabs and tiles

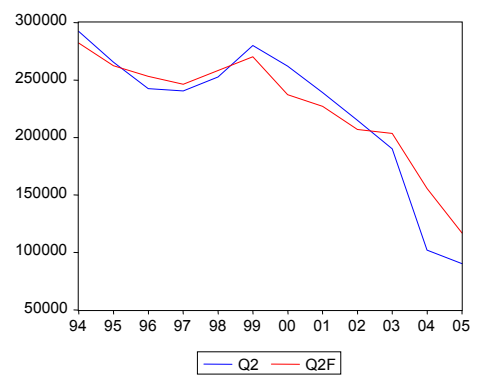

Fig. 3. Labour

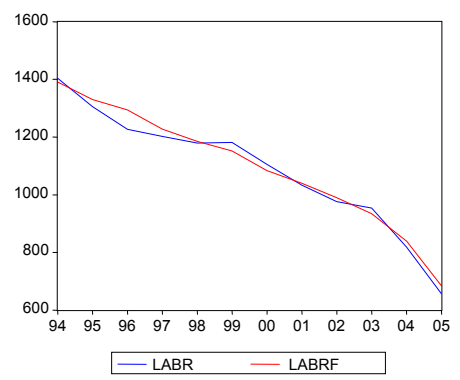

Overall, the quantities produced of marble blocks, slabs and tiles that represent the most important products of the company tend to fall. This is mainly due to the dilapidated and obsolescence of production tools on the one hand and the destruction of industrial plants by 
multiple acts of sabotage between 1993 and 1997 on the other hand. The financial difficulties have made the replacements of the production tools very difficult. In addition, the decreasing numbers of the workers affects considerably these quantities. The number of workers used have not ceased to decline. The company management has facilitated the voluntary departure of a significant number of workers because of the financial problems confronting the company. In addition, workers who retire are not replaced.

Fig. 4. Quantities sold of marble blocks

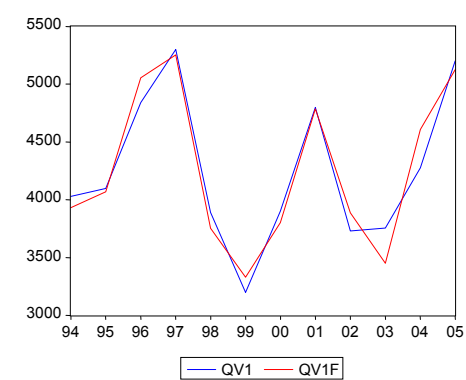

Fig. 5. Quantities sold of slabs and tiles

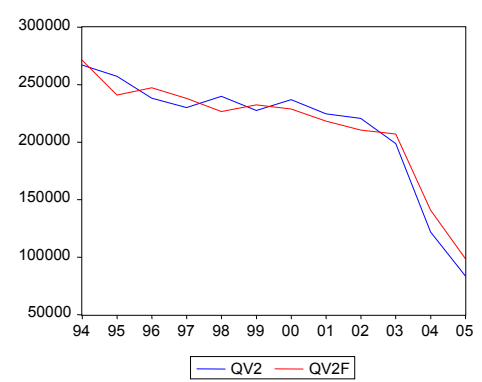

The quantities sold of marble blocks are fairly stable. In fact, they reflect a steady demand in the marketplace. The quantities sold of slabs and tiles are experiencing a slow decline until 2003. In this date the decline becomes quite important. The quantities sold depend largely on the quantities produced.

\subsection{Validity Tests of the Model}

To evaluate the precision, the stability of the model and its ability to generate historical data, three tests adapted to the situation studied are considered: the simulation test, the multiplier test and the dynamic elasticity. The simulation test is used to calculate the quadratic average in value and in percentage of simulation errors of endogenous variables in order to judge the precision of the model. The two last tests are used to test the stability of the model and in the sensitivity analysis.

\subsubsection{Simulation tests}

The quadratic average and the quadratic average in percentage of simulation errors of some endogenous variables of the two first blocks are shown in Table 1.

The quadratic averages in value and in percentage of the simulation errors of endogenous variables considered are acceptable, the gap between the simulated values and historical ones are small. 


\subsubsection{Multiplier test}

When the values of an exogenous variable in the considered historical range undergo shock, the multiplier is calculated as follows:

$$
M=\left(Y_{t}^{s}-Y_{t}^{b}\right) / \Delta X
$$

where:

$Y_{t}^{s}-$ value of the endogenous variable simulated after shock,

$Y_{t}^{b}-$ value of the base endogenous variable,

$\Delta X$ - variation in the exogenous variable.

Several scenarios have been discussed for permanent and local disturbances; this section will include some ones of them. Moreover, just the last five multipliers values in each case will be shown.

Table 1. Quadratic average in value and in percentage of simulation errors of some endogenous variables

\begin{tabular}{|l|r|r|r|}
\hline & \multicolumn{1}{|c|}{ Average } & \multicolumn{1}{c|}{$\begin{array}{c}\text { Quadratic } \\
\text { average }\end{array}$} & $\begin{array}{c}\text { Quadratic } \\
\text { average (\%) }\end{array}$ \\
\hline $\mathrm{Q}_{1}$ & 20603.93 & 700.84 & 3.50 \\
\hline $\mathrm{Q}_{2}$ & 241550.40 & 18248.28 & 11.40 \\
\hline $\mathrm{Q}_{3}$ & 117792.60 & 8269.72 & 11.00 \\
\hline $\mathrm{Q}_{4}$ & 62310.27 & 3424.76 & 3.70 \\
\hline $\mathrm{QV}_{1}$ & 4399.73 & 150.30 & 7.04 \\
\hline $\mathrm{QV}_{2}$ & 227131.60 & 10049.87 & 9.75 \\
\hline $\mathrm{QV}_{3}$ & 108537.40 & 9122.41 & 13.60 \\
\hline $\mathrm{QV}_{4}$ & 60945.34 & 4009.26 & 2.60 \\
\hline $\mathrm{EFF}_{1}$ & 503.73 & 14.03 & 3.60 \\
\hline $\mathrm{EFF}_{2}$ & 376.00 & 10.62 & 1.60 \\
\hline $\mathrm{EFF}_{3}$ & 166.93 & 2.56 & 7.00 \\
\hline $\mathrm{EFF}_{4}$ & 116.76 & 5.97 & 2.29 \\
\hline $\mathrm{Labour}$ & 1163.42 & 24.51 & 3.70 \\
\hline $\mathrm{RR}_{1}$ & 50765.98 & 1953.37 & 7.04 \\
\hline $\mathrm{RR}_{2}$ & 218983.10 & 12845.23 & 9.75 \\
\hline $\mathrm{RR}_{3}$ & 107530.80 & 8746.36 & 13.60 \\
\hline $\mathrm{RR}_{4}$ & 22829.05 & 1840.54 & 4.25 \\
\hline $\mathrm{RR}$ & 421040.00 & 18601.07 & \\
\hline $\mathrm{S}$ & & & \\
\hline
\end{tabular}

Source: own calculations. 


\section{Scenario 1}

\section{Permanent disturbances}

Case 1: A 10\% increase in the values of unit labour cost on its historical range has given for some endogenous variables the multipliers shown in Table 2. This increase in the unit labour cost has caused:

- A decrease in the workers used in the production. Indeed an increase in unit labour cost may cause a reduction in the labour expressed in number of workers. In addition, the labour used in the production is largely explained by unit labour cost.

- A decrease in the quantity produced of marble blocks, slabs and tiles, marble derivative and quarries aggregates, which are largely explained by the labour.

- A decrease in the quantities sold for the four products caused by a decrease in their quantities produced.

Case 2: A 100\% increase in the values of unit labour cost gives the same multipliers as those obtained for the first case of this scenario.

$\underline{\text { Local disturbances }}$

A $10 \%$ increase in the second value of unit labour cost has given the results presented in Table 2. These results are the sums of multipliers for each value of the endogenous variable. It can be noticed that those values are very close to the multipliers found in the case of permanent scenario 1 .

\section{$\underline{\text { Scenario } 2}$}

\section{Permanent disturbances}

Case 1: A 10\% increase in the values of unit sale price of marble blocks on its historical range has given the multipliers shown in Table 2. This increase has caused:

- A decrease in the quantities sold of marble blocks, which are largely explained by the unit sale price.

- An increase in the income related to the product caused by the fact that incomes are the product of the quantities sold and unit sale price. The increase in unit sale price has had a greater impact on the income.

Case 2: A 100\% increase in the values of unit sale price of marble blocks gives the same multipliers as those obtained for the first case of this scenario. 
Local disturbances

A $10 \%$ increase in the second value of the unit sale price of marble blocks gives the multipliers presented in Table 2. The multipliers obtained in this case are very close to those found in the permanent case of scenario 2 .

Table 2. The multipliers

\begin{tabular}{|c|c|c|c|c|c|c|}
\hline \multicolumn{7}{|c|}{ Multiplier } \\
\hline & \multicolumn{5}{|c|}{ Permanent disturbances } & $\begin{array}{l}\text { Local distur- } \\
\text { bances }\end{array}$ \\
\hline & \multicolumn{5}{|c|}{ Scenario 1} & Scenario 1 \\
\hline & \multicolumn{5}{|c|}{ Case 1} & Case 2 \\
\hline $\mathrm{Q}_{1}$ & -15.69 & -16.93 & -18.12 & -19.36 & -20.64 & -33.17 \\
\hline $\mathrm{Q}_{2}$ & -326.00 & -331.70 & -331.80 & -353.80 & -387.60 & -287.20 \\
\hline $\mathrm{Q}_{3}$ & -34.26 & -112.47 & -97.12 & -87.71 & -88.01 & -67.6 \\
\hline $\mathrm{Q}_{4}$ & -46.34 & -51.54 & -56.03 & -58.23 & -56.87 & -89.40 \\
\hline $\mathrm{QV}_{1}$ & -0.40 & -0.38 & -0.39 & -0.45 & -0.53 & -0.927 \\
\hline $\mathrm{QV}_{2}$ & -179.35 & -179.22 & -179.12 & -185.43 & -196.70 & -160.63 \\
\hline $\mathrm{QV}_{3}$ & -26.54 & -105.79 & -91.43 & -83.09 & -84.30 & -50.17 \\
\hline $\mathrm{QV}_{4}$ & -50.70 & -56.46 & -61.45 & -63.93 & -62.49 & -98.40 \\
\hline $\mathrm{EFF}_{1}$ & -1.13 & -1.22 & -1.31 & -1.39 & -1.49 & -2.39 \\
\hline $\mathrm{EFF}_{2}$ & -0.93 & -0.93 & -0.93 & -0.94 & -0.95 & -0.92 \\
\hline $\mathrm{EFF}_{3}$ & -0.03 & -0.03 & -0.03 & -0.03 & -0.03 & -0.03 \\
\hline $\mathrm{EFF}_{4}$ & -0.15 & -0.17 & -0.18 & -0.18 & -0.18 & -0.27 \\
\hline Labour & -2.26 & -2.36 & -2.46 & -2.56 & -2.66 & -3.62 \\
\hline $\mathrm{RR}_{1}$ & -6.25 & -6.45 & -6.01 & -4.83 & -6.73 & -8.83 \\
\hline $\mathrm{RR}_{2}$ & -243.38 & -241.23 & -226.76 & -263.87 & -301.35 & -144.04 \\
\hline $\mathrm{RR}_{3}$ & -154.38 & -143.25 & -130.38 & -125.31 & -130.34 & -110.55 \\
\hline $\mathrm{RR}_{4}$ & -25.70 & -29.92 & -33.37 & -33.75 & -38.05 & -51.60 \\
\hline \multirow[t]{3}{*}{$\mathrm{RR}$} & -429.93 & -420.66 & -396.53 & -427.77 & -476.49 & -274.48 \\
\hline & \multicolumn{5}{|c|}{ Scenario 2} & Scenario 2 \\
\hline & \multicolumn{5}{|c|}{ Case 1} & Case 2 \\
\hline $\mathrm{QV}_{1}$ & -21.89 & -51.67 & -54.73 & -33.39 & -11.59 & -50.17 \\
\hline \multirow[t]{3}{*}{$\mathrm{RR}_{1}$} & 3749 & 3071 & 3059 & 3759 & 3268 & 3578 \\
\hline & \multicolumn{5}{|c|}{ Scenario 3} & Scenario 3 \\
\hline & \multicolumn{5}{|c|}{ Case 1} & Case 2 \\
\hline $\mathrm{Q}_{1}$ & 26185 & 28874 & 28679 & 27521 & 27970 & 27121 \\
\hline $\mathrm{QV}_{1}$ & 275 & -100 & 363 & 1020 & 955 & 628 \\
\hline \multirow[t]{3}{*}{$\mathrm{RR}_{1}$} & 4470 & -1622 & 5561 & 10918 & 12097 & 6304 \\
\hline & \multicolumn{5}{|c|}{ Scenario 4} & Scenario 4 \\
\hline & \multicolumn{5}{|c|}{ Case 1} & Case 2 \\
\hline $\mathrm{QV}_{1}$ & 0.13 & -0.08 & 0.00 & 0.17 & 0.22 & 0.15 \\
\hline $\mathrm{RR}_{1}$ & 2.14 & -1.44 & 0.01 & 1.89 & 2.78 & 1.27 \\
\hline
\end{tabular}

Source: own calculations.

\section{$\underline{\text { Scenario } 3}$}

\section{Permanent disturbances}

Case 1: An increase of $10 \%$ in the values of the capacity used in the production of marble blocks on its historical range has given the multipliers shown in Table 2. This increase has caused: 
- An overall increase in the quantities produced of marble blocks caused by the expand in the production tool.

- An increase in quantities sold of marble blocks which are largely explained by the quantity produced.

- An increase in the revenue of marble blocks due to the increase in quantities sold.

Case 2: An increase of $100 \%$ in the values of the capacity used in the production of marble blocks gives exactly the same multipliers obtained for the first case of the third scenario.

\section{Local disturbances}

An increase of $10 \%$ in the second value of the capacity used in the production of marble blocks has given the results presented in Table 2 . The multipliers presented in Table 2 are very close to the multipliers found in the permanent case of scenario 3 .

\section{$\underline{\text { Scenario } 4}$}

\section{Permanent disturbances}

Case 1: A 10\% increase in the values of the orders for marble blocks on its historical range has given the multipliers shown in Table 2 .

An increase in orders related to blocks of marble led overall to:

- An increase in quantities sold of this product largely explained by the orders registered.

- An increase in the income of this product due to the increase in quantities sold.

Case 2: A 100\% increase in the values of the orders for marble blocks gives the same multipliers as those obtained for the first case of the same scenario.

\section{Local disturbances}

A $10 \%$ increase in the second value of the orders for marble blocks has given the multipliers shown in Table 2. It is noted that the multipliers presented in Table 2 are very close to the multipliers found in the permanent case of scenario 4 .

Overall multipliers found in the local case are very close to multipliers found in the permanent case for each scenario. This shows good stability of the model developed. Indeed, different increases in the historical range of an exogenous variable in the first block model have almost the same effect after simulation on the endogenous variables explained by this exogenous variable. As well, an increase in one value of an exogenous variable in the local case gives nearly the same values of multipliers obtained in the permanent disturbances. 
These results are very important for proving the stability of the model. In addition, they give the manager the effects of the increasing on the key variables.

\subsubsection{Dynamic Elasticity Test}

When the values of an exogenous variable in the considered historical range undergo shock, the dynamic elasticity is calculated as follows:

$$
E(X)=\left(X_{t} / Y_{t}^{b}\right) \cdot\left(Y_{t}^{s}-Y_{t}^{b}\right) / \Delta X
$$

where:

$Y_{t}^{b} \mathrm{Y}_{\mathrm{t}}^{\mathrm{b}}$ - value of the endogenous variable base,

$X_{t}$ - value of the exogenous variable,

$Y_{t}^{s}-Y_{t}^{b}$ - change in the endogenous variable $\mathrm{Y}$ simulated after disturbance done on $\mathrm{X}$,

$\Delta X$ - variation in the exogenous variable.

In the calculation of the dynamic elasticity, the same scenarios used in the calculation of the multipliers will be considered. The values obtained for the elasticities in each case are shown in the Table 3.

\section{$\underline{\text { Scenario } 1}$}

Permanent disturbances

Case 1: A 10\% increase in the values of the unit labour cost for marble blocks has caused:

- A decrease in the quantities produced of marble blocks, slabs and tiles, marble derivatives and quarries aggregates.

- A decrease in the quantities sold of the products of the corporation.

- A decrease in the staffing.

- A decrease in the incomes of sales of the products of the corporation.

Case 2: The increase in the unit labour cost from $10 \%$ to $100 \%$ has amplified the impact on the endogenous variables.

\section{Local disturbances}

After a disturbance on the second value of unit labour cost, the elasticities regain balance. These situations can be shown below for some endogenous variables graphically (see Figures 6-9). 


\section{$\underline{\text { Scenario } 2}$}

\section{Permanent disturbances}

Case 1: An increase of $10 \%$ in the unit sale price gives the following results:

- A decrease of the quantities sold of marble blocks.

- An increase in the income of the marble blocks sales.

Case 2: The exogenous variable has risen from $10 \%$ to $100 \%$ and has increased the impact on the quantities sold and the income of sale of marble blocks.

\section{Local disturbances}

Case 2: After a disturbance on a value of the exogenous variable sale unit price, the elasticities find balance.

\section{$\underline{\text { Scenario } 3}$}

\section{Permanent disturbances}

Case 1: An increase of $10 \%$ in the values of the capacity used in the production of marble blocks lead to an increase in the quantities produced, the quantities sold and the incomes of the marble blocks.

Case 2: The increase of the capacity used in the production of marble blocks from $10 \%$ to $100 \%$ has amplified the impact on the quantities produced, the quantities sold and the income of sales of the marble blocks.

\section{Local disturbances}

Case 2: After a disturbance on a value of the exogenous variable capacity used in the production of marble blocks, the elasticities regain balance.

Table 3. Dynamic elasticities

\begin{tabular}{|c|c|c|c|c|c|c|c|c|c|c|c|c|c|c|c|}
\hline & \multicolumn{15}{|c|}{ Dynamic elasticity } \\
\hline & \multicolumn{5}{|c|}{ Permanent disturbances } & \multicolumn{5}{|c|}{ Permanent disturbances } & \multicolumn{5}{|c|}{ Local disturbances } \\
\hline & \multicolumn{5}{|c|}{ Scenario 1} & \multicolumn{5}{|c|}{ Scenario 1} & \multicolumn{5}{|c|}{ Scenario 1} \\
\hline & \multicolumn{5}{|c|}{ Case 1} & \multicolumn{5}{|c|}{ Case 2} & \multicolumn{5}{|c|}{ Case 2} \\
\hline $\mathrm{Q}_{1}$ & -0.22 & -0.26 & -0.33 & -0.43 & -0.60 & -0.39 & -0.47 & -0.6 & -0.78 & -1.10 & -0.01 & -0.01 & -0.02 & -0.02 & -0.03 \\
\hline $\mathrm{Q}_{2}$ & -0.36 & -0.43 & -0.47 & -0.73 & -1.25 & -0.65 & -0.78 & -0.8 & -1.33 & -2.27 & $-3 \mathrm{E}-4$ & $-7 \mathrm{E}-5$ & $-1 \mathrm{E}-5$ & $4 \mathrm{E}-6$ & $-1 \mathrm{E}-6$ \\
\hline $\mathrm{Q}_{3}$ & -0.34 & -0.28 & -0.24 & -0.23 & -0.28 & -0.62 & -0.51 & -0.4 & -0.43 & -0.51 & 0.106 & 0.101 & 0.093 & 0.071 & 0.052 \\
\hline Q. & -0.51 & -0.57 & -0.63 & -0.71 & -0.85 & -0.92 & -1.04 & -1.1 & -1.30 & -1.55 & -0.10 & -0.09 & -0.09 & -0.09 & -0.10 \\
\hline Q) & -0.02 & -0.02 & -0.03 & -0.03 & -0.04 & -0.04 & -0.05 & -0.0 & -0.06 & -0.07 & $-2 \mathrm{E}-3$ & 0.02 & 0.01 & -0.01 & -0.02 \\
\hline Q & -0.20 & -0.23 & -0.25 & -0.42 & -0.75 & -0.37 & -0.41 & -0.4 & -0.77 & -1.36 & $3 \mathrm{E}-4$ & $1 \mathrm{E}-4$ & $5 \mathrm{E}-5$ & $3 \mathrm{E}-5$ & $2 \mathrm{E}-5$ \\
\hline Q & -0.33 & -0.27 & -0.23 & -0.23 & -0.28 & -0.60 & -0.49 & -0.4 & -0.42 & -0.51 & 0.10 & 0.09 & 0.09 & 0.06 & 0.05 \\
\hline Q & -0.61 & -0.62 & -0.70 & -0.75 & -0.91 & -1.11 & -1.13 & -1.2 & -1.37 & -1.67 & -0.12 & -0.10 & -0.10 & -0.10 & -0.11 \\
\hline EH & -0.62 & -0.77 & -0.95 & -1.29 & -2.17 & -1.13 & -1.40 & -1.7 & -2.36 & -3.96 & -0.03 & -0.04 & -0.05 & -0.06 & -0.10 \\
\hline EH & -0.69 & -0.79 & -0.90 & -1.14 & -1.68 & -1.26 & -1.44 & -1.6 & -2.07 & -3.06 & $-5 \mathrm{E}-5$ & $1 \mathrm{E}-5$ & $-2 \mathrm{E}-6$ & 7E-7 & $-2 \mathrm{E}-7$ \\
\hline EH & -0.06 & -0.06 & -0.06 & -0.07 & -0.09 & -0.11 & -0.11 & -0.1 & -0.13 & -0.17 & $4 \mathrm{E}-4$ & 0.00 & $-9 \mathrm{E}-4$ & 0.00 & $-3 \mathrm{E}-4$ \\
\hline
\end{tabular}




\begin{tabular}{|c|c|c|c|c|c|c|c|c|c|c|c|c|c|c|c|}
\hline $\mathrm{EH}$ & -0.39 & -0.50 & -0.64 & -0.84 & -1.13 & -0.72 & -0.92 & -1.18 & -1.53 & -2.06 & -0.05 & -0.06 & -0.07 & -0.09 & -0.12 \\
\hline $\mathrm{La}$ & -0.54 & -0.64 & -0.76 & -0.98 & -1.46 & -0.99 & -1.17 & -1.39 & -1.79 & -2.67 & -0.02 & -0.02 & -0.03 & -0.03 & -0.05 \\
\hline $\mathrm{RH}$ & -0.02 & -0.02 & -0.03 & -0.03 & -0.03 & -0.04 & -0.05 & -0.06 & -0.06 & -0.07 & $-2 \mathrm{E}-3$ & 0.02 & 0.01 & -0.01 & -0.02 \\
\hline $\mathrm{RH}$ & -0.20 & -0.23 & -0.25 & -0.42 & -0.75 & -0.37 & -0.42 & -0.45 & -0.77 & -1.36 & $3 \mathrm{E}-4$ & $1 \mathrm{E}-4$ & $5 \mathrm{E}-5$ & $3 \mathrm{E}-5$ & $2 \mathrm{E}-5$ \\
\hline $\mathrm{RH}$ & -0.33 & -0.27 & -0.23 & -0.23 & -0.28 & -0.60 & -0.49 & -0.42 & -0.42 & -0.51 & 0.10 & 0.09 & 0.09 & 0.06 & 0.05 \\
\hline $\mathrm{RH}$ & -0.61 & -0.62 & -0.70 & -0.75 & -0.91 & -1.11 & -1.13 & -1.28 & -1.37 & -1.67 & -0.12 & -0.10 & -0.10 & -0.10 & -0.11 \\
\hline $\mathrm{RH}$ & -0.21 & -0.22 & -0.22 & -0.30 & -0.42 & -0.38 & -0.40 & -0.41 & -0.55 & -0.77 & 0.02 & 0.02 & 0.02 & 0.02 & 0.01 \\
\hline & \multicolumn{10}{|c|}{ Scenario 2} & \multicolumn{5}{|c|}{ Scenario 2} \\
\hline & \multicolumn{5}{|c|}{ Case 1} & \multicolumn{5}{|c|}{ Case 2} & \multicolumn{5}{|c|}{ Case 2} \\
\hline Q) & -0.01 & -0.09 & -0.19 & -0.20 & -0.15 & -0.02 & -0.16 & -0.35 & -0.37 & -0.28 & 0.00 & 0.13 & 0.07 & -0.04 & -0.05 \\
\hline \multirow[t]{3}{*}{$\mathrm{RH}$} & 0.99 & 0.88 & 0.87 & 0.93 & 1.03 & 1.96 & 1.66 & 1.29 & 1.24 & 1.44 & 0.00 & 0.13 & 0.07 & -0.04 & -0.05 \\
\hline & \multicolumn{10}{|c|}{ Scenario 3} & \multicolumn{5}{|c|}{ Scenario 3} \\
\hline & \multicolumn{5}{|c|}{ Case 1} & \multicolumn{5}{|c|}{ Case 2} & \multicolumn{5}{|c|}{ Case 2} \\
\hline$Q_{1}$ & 0.71 & 0.72 & 0.71 & 0.73 & 0.79 & 1.30 & 1.32 & 1.30 & 1.33 & 1.44 & 0.00 & 0.00 & 0.00 & 0.00 & 0.00 \\
\hline Q) & 0.03 & -0.01 & 0.04 & 0.08 & 0.07 & 0.05 & -0.02 & 0.07 & 0.15 & 0.12 & 0.029 & -0.025 & -0.042 & 0.00 & 0.02 \\
\hline $\mathrm{RH}$ & 0.03 & -0.01 & 0.04 & 0.08 & 0.07 & 0.05 & -0.02 & 0.07 & 0.15 & 0.12 & 0.029 & -0.025 & -0.042 & 0.00 & 0.02 \\
\hline & \multicolumn{10}{|c|}{ Scenario 4} & \multicolumn{5}{|c|}{ Scenario 4} \\
\hline & \multicolumn{5}{|c|}{ Case 1} & \multicolumn{5}{|c|}{ Case 2} & \multicolumn{5}{|c|}{ Case 2} \\
\hline Q) & 0.24 & -0.103 & 0.001 & 0.42 & 0.48 & 0.44 & -0.188 & 0.002 & 0.76 & 0.87 & 0.002 & -0.10 & -0.087 & 0.12 & 0.148 \\
\hline $\mathrm{RH}$ & 0.24 & -0.103 & 0.001 & 0.42 & 0.48 & 0.44 & -0.188 & 0.002 & 0.76 & 0.87 & 0.002 & -0.10 & -0.087 & 0.12 & 0.148 \\
\hline
\end{tabular}

Source: own calculations.

\section{$\underline{\text { Scenario } 4}$}

\section{Permanent disturbances}

Case 1: The increase in the orders for marble blocks has caused an increase in the quantities produced and the income of sales of the marble blocks.

Case2: After this disturbance, the elasticities regain balance.

\section{$\underline{\text { Local disturbances }}$}

Case 2: After a disturbance on a value of the orders for marble blocks, elasticities found overall balance.

For each scenario considered in this part, we note that the increase in the disturbances in the exogenous variables amplify the impact on the endogenous variables in the permanent case. In the local case, after a shock on a value of an exogenous variable, the elasticities regain balance. This proves once again the good stability of the model built. 
Fig. 6. The elasticity of the quantities produced of marble blocks

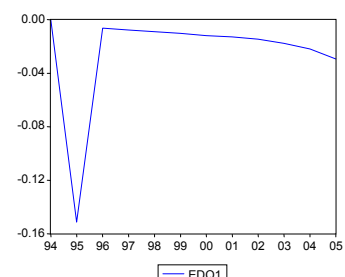

Fig. 7. The elasticity of the quantities produced of slabs and tiles

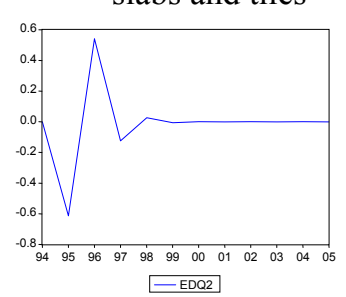

Fig. 8. The elasticity of the total income

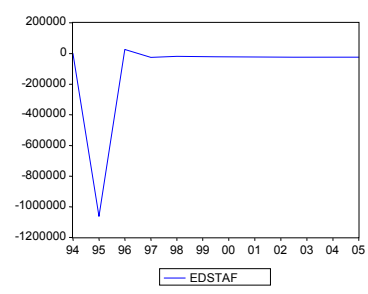

Fig. 9. The elasticity of labour

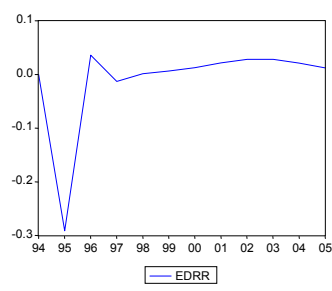

The model is constructed, fit and validated so it can be used for forecasting and also for testing "what if?" sensitivity analysis.

\section{Forecasting}

Forecasting is a very important step. Its aim is to use the model developed from company data to generate future values essential to the company. In our case we use the time series that works well for the prediction of a few key variables from the company for the period 2006-2010. To this end we have calculated on the one hand, forecasts of endogenous variables from exogenous variables and planned another part of the forecasts of endogenous and exogenous variables.

\subsection{Forecast of Endogenous Variables}

The anticipation of the endogenous variable $Y_{(t+1)}$ requires that of $X_{(t+1)}$. In this case forecasting techniques will be applied to exogenous variables $X_{(t)}$. The model estimated and simulated has been used over a period of five years. It has given Figures 10-14 for some endogenous variables of the first block.

Fig. 10. Production quantities of marble blocks

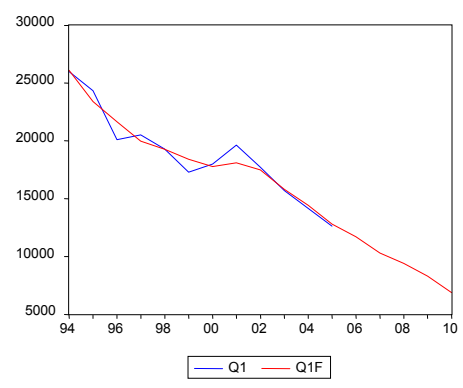

Fig. 11. Production quantities of slabs and tiles

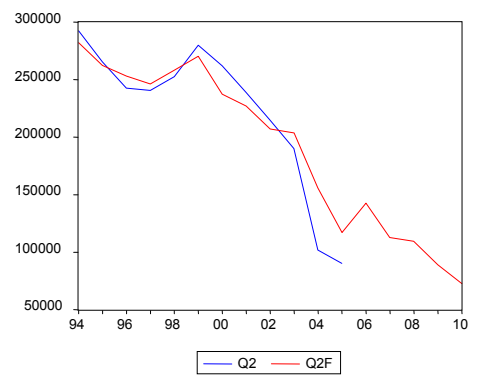

Fig. 12. Labour

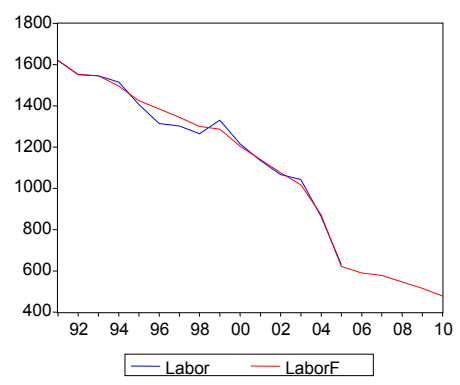


Fig. 13. The quantities sold of marble blocks

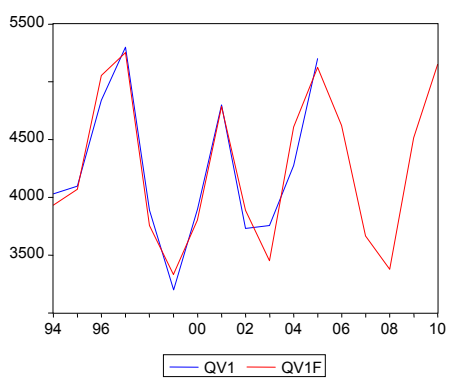

Fig. 14. The quantities sold of slabs and tiles

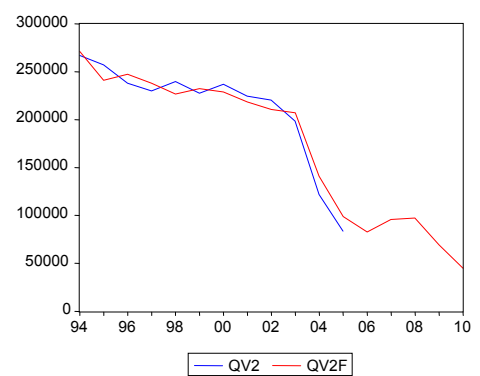

The forecasts of the endogenous variables have led to very acceptable values for each variable considered. As the figures show the predictive values have broadly the same trend as the historical ones.

The quantity produced of the marble blocks, the slabs and tiles will continue to decline because of the decrease in capacity used and the labour expressed in the number of workers. The quantity sold of the marble blocks will preserve its stability while the quantity sold in the slabs and the tiles will overall continue to decrease. The labour also will continue to decrease. The situation of the corporation is very critical. It will be impossible to reach the objectives. An investment in production capacities is very urgent.

\subsection{Forecast Endogenous and Exogenous Variables}

Another way is to predict all the variables of the model, namely endogenous and exogenous variables and then do a simulation on the period considered. This has given the Figures 15-19.

Fig. 15. Production quantities of marble blocks

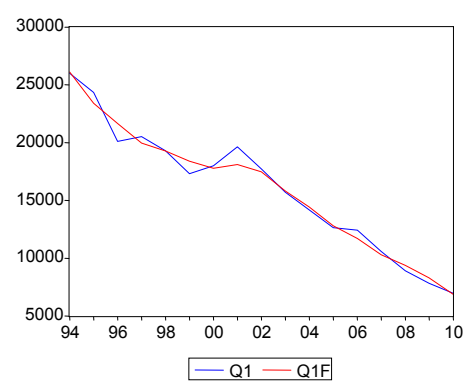

Fig. 16. Production quantities of slabs and tiles

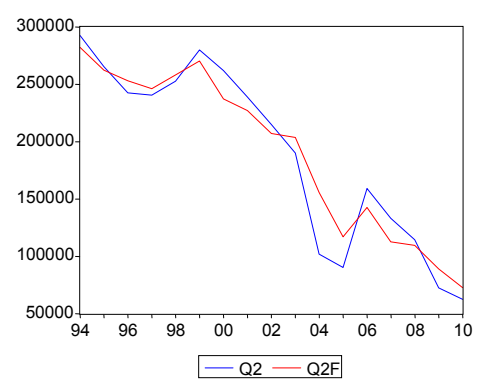

Fig. 17. Labour

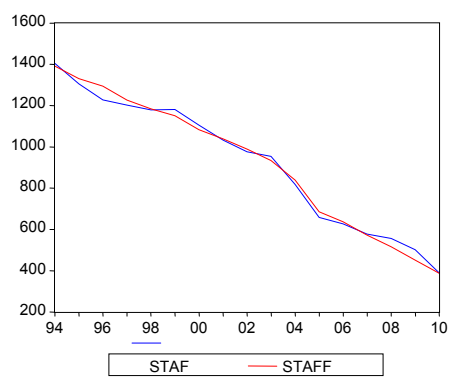


Fig. 18. The quantities sold of marble blocks

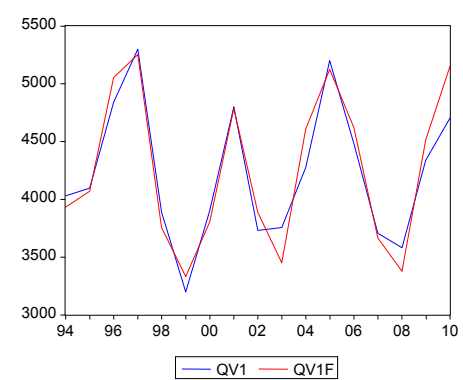

Fig. 19. The quantities sold of slabs and tiles

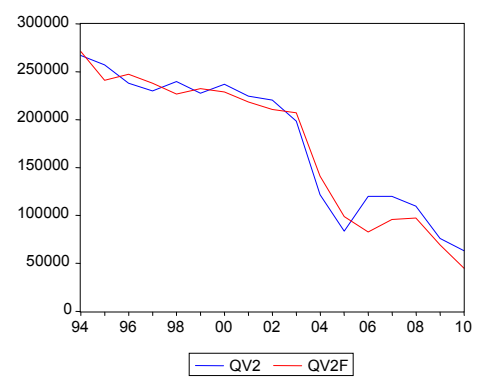

\subsection{Validity of the Forecast}

The quadratic average and the quadratic average in percentage of simulation errors of the predicted values of endogenous variables for the forecast period have yielded to the results shown in Table 4.

Table 4. Quadratic average in value and in percentage of simulation errors

\begin{tabular}{|l|r|r|}
\hline \multicolumn{1}{|c|}{$\begin{array}{c}\text { Endogenous } \\
\text { variable }\end{array}$} & \multicolumn{1}{|c|}{$\begin{array}{c}\text { Quadratic } \\
\text { average }\end{array}$} & $\begin{array}{r}\text { Quadratic } \\
\text { average (\%) }\end{array}$ \\
\hline $\mathrm{Q}_{1}$ & 461.49 & 4.01 \\
$\mathrm{Q}_{2}$ & 14798.65 & 15.02 \\
$\mathrm{Q}_{3}$ & 4608.37 & 4.51 \\
$\mathrm{Q}_{4}$ & 1641.99 & 11.04 \\
$\mathrm{QV}_{1}$ & 241.59 & 5.13 \\
$\mathrm{QV}_{2}$ & 22494.44 & 21.00 \\
$\mathrm{QV}_{3}$ & 9309.92 & 8.94 \\
$\mathrm{QV}_{4}$ & 16000.00 & 5.11 \\
$\mathrm{EFF}_{1}$ & 6.93 & 6.00 \\
$\mathrm{EFF}_{2}$ & 20.00 & 15.00 \\
$\mathrm{EFF}_{3}$ & 2.17 & 1.12 \\
$\mathrm{EFF}_{4}$ & 5.06 & 11.00 \\
$\mathrm{Labour}$ & 29.48 & 5.21 \\
\hline
\end{tabular}

Source: own calculations.

The quadratic average and quadratic average in percentage have given good results, the gap between the simulated values and the predicted values are generally small. The model built on data from the company is validated and can be used in the prediction in the corporation. 


\section{Conclusions}

The model developed in this work is a corporate planning model for the Algerian national marble company. This model is a precise model of the essential functions of the company: production, marketing and finance. It permits to the corporation managers a better understand of the business and its functional relationships. Through simulation exercises, it can be used as a tool in short-term forecasting. It contributes in the evaluation of different management scenarios proving so its usefulness as a tool of decision-making. A first evaluation of the model has proven successful. Indeed, simulation tests were satisfactory.

The results obtained confirm the fact that this model can assist managers in improving their authority to make decisions in Algerian companies living in a changing economic environment, marked by a market in growing complexity.

\section{Notes}

${ }^{1}$ Dinkel, Fuerst (1986).

${ }^{2}$ Shim, McGlade (1984).

${ }^{3}$ Shim, McGlade (1984).

${ }^{4}$ Kingston (1977).

${ }^{5}$ Naylor (1971).

${ }^{6}$ Grinyer, Wooller (1975).

${ }^{7}$ Shim, McGlade (1984).

${ }^{8}$ Hammond (1974), Power (1975), Shim, Siegel, Hartman (1998).

${ }^{9}$ Shim, Siegel, Hartman (1998).

${ }^{10}$ Mattessich (1964).

${ }^{11}$ Clarkson (1962).

${ }^{12}$ Hillier (1963).

${ }^{13}$ Hertz (1964).

${ }^{14}$ Gershefski (1969).

${ }^{15}$ Dickens, Frazier (1970).

${ }^{16}$ Naylor (1971).

${ }^{17}$ Naylor (1971).

${ }^{18}$ Carter (1973).

${ }^{19}$ Naylor, Gattis (1976).

${ }^{20}$ Clarke, Tobias (1995).

${ }^{21}$ Kivijärvi, Tuominen (1989). 
${ }^{22}$ Lotz, Yen (1992).

${ }^{23}$ Kirca, Koksalan (1996).

${ }^{24}$ Kivijärvi, Tuominen (1997).

${ }^{25}$ Shim, Siegel (2001).

${ }^{26}$ Mohamed (1999).

${ }^{27}$ Tarrazo, Gutierrez (2000).

${ }^{28}$ Bhutta, Huq, Frazier and Mohamed (2003).

${ }^{29}$ Mulvey, Shetty (2004).

${ }^{30}$ Kaye (1994).

\section{References}

Bhutta, K.S., Huq, F., Frazier, G. \& Mohamed, Z. (2003). An Integrated Location, Production, Distribution and Investment Model for a Multinational Corporation. International Journal of Production Economics, 86, 201-216.

Carter, E.E. (1973). A Simultaneous Equation Approach to Financial Planning: Comment. The Journal of Finance, 28, 1035-38.

Clarke, S. \& Tobias, A.M. (1995). Complexity in Corporate Modelling: a Review. Business History, 37 (2), 17-44.

Clarkson, G.PE. (1962). Portfolio Selection: A Simulation of Trust Investment. New Jersey: Prentice- Hall Inc.

Dickens, J.H \& Frazier, G.D. (1970). Linear Programming in Corporate Simulation. Washington, DC.

Dinkel, J.J. \& Fuerst, W.L. (1986). Corporate Planning Optimization Models: Integrative Aspects and Microcomputers. Infor Journal, 24 (2), 101-115.

Gershefski, G.W. (1969). Building a Corporate Financial Model. Harvard Business Review, 47, 61-72.

Grinyer, P.D. \& Wooller, J. (1975). Corporate Models Today - a New Tool for Financial Management. London.

Hammond, J.S. (1974). Do's and Don'ts of Computer Models for Planning. Harvard Business Review, 52, 110-123. 
Hertz, D. (1964). Risk Analysis in Capital Budgeting. Harvard Business Review, XLII, 95106.

Hillier, F. (1963). Derivation of Probabilistic Information for the Evaluation of Risky Investments. Management Science, 9, 443-57.

Kaye, R.K. (1994). Financial Planning Models. London: Academic Press.

Kingston, P.L. (1977). Anatomy of a Financial Model. Management Planning, 26, 1-7.

Kirca, O. \& Koksalan, M. (1996). An Integrated Production and Financial Planning Model and an Application. II Transactions, 19(8), 765-784.

Kivijarvi, H. \& Tuominen, M. (1987). Corporate Wide Information Requirements Analysis and Financial, Marketing and Production Planning. Engineering Costs and Production Economics, 12, 346.

Kivijarvi, H. \& Tuominen, M. (1989). Computer-Based Multi-Attribute Simulation of Production and Financial Strategies. Engineering Costs and Production Economics, 17, 331341.

Kivijarvi, H. \& Tuominen, M. (1997). Decision Aid in Strategic Planning and Analysis of Wood-pressing Company. Computers Industrial Engineering, 31(1/2), 467-470.

Lotz, S. C. \& Yen, D. (1992). A Telecommunications Strategic Planning Model. International Journal of Information Management, 12, 272-286.

Mattessich, R. (1961). Budgeting Models and Systems Simulation. Accounting Review, 36, 384-97.

Mohamed, Z.M. (1999). An Integrated Production-Distribution Model for a Multi-national Company Operating under Varying Exchange Rates. International Journal of Production Economics, 58, 81-92.

Mulvey, M. \& Shetty, B. (2004). Financial Planning via Multi-stage Stochastic Optimization. Computers \& Operations Research, 31, 1-20.

Naylor, T.H. (1971). Computer Simulation Experiments with Models of Economic Systems. USA: John Wiley and Sons, Inc.

Naylor, T.H. \& Gattis, D.R. (1976). Corporate Planning Models. California Management Review, 18, 69-78.

Power, P.D. (1975). Computers and Financial Planning. Long Range Planning, 8, 53-59. 
Shim, J.K. \& McGlade, R. (1984). The Use of Corporate Planning Models: Past, Present and Future. Journal of the Operational Research Society, 35, 85-893.

Shim, J.K. \& Siegel, J.G. (2001). Handbook of Financial Analysis, Forecasting and Modeling. USA: Prentice Hall Press.

Shim, J.K., Siegel, J.G. \& Hartman, S.W. (1998). Schaum's Quick Guide to Business Formulas: 201 Decision Making Tools for Business, Finance and Accounting Students. USA: Net Library Inc.

Tarrazo, M. \& Gutierrez, L.(2000). Theory and Methodology Economic Expectations, Fuzzy Sets and Financial Planning. European Journal of Operational Research, 126, 89-105.

\section{Annexes}

Table A1. Estimated quantities of marble and tiles

\begin{tabular}{|l|r|r|r|}
\hline \multicolumn{1}{|c|}{ Variable } & \multicolumn{1}{|c|}{ Standard error } & t-Statistics & \multicolumn{1}{c|}{ Probability } \\
\hline $\mathrm{CU}_{1}$ & 5424.4930 & 2.4134 & 0.0344 \\
\hline $\mathrm{CU}_{1}(-1)$ & 5045.9280 & 2.7802 & 0.0179 \\
\hline $\mathrm{EFF}_{1}$ & 4.2808 & 3.2347 & 0.0079 \\
\hline
\end{tabular}

Source: own calculations.

Table A2. Estimated quantities of slabs blocks

\begin{tabular}{|l|r|r|r|}
\hline \multicolumn{1}{|c|}{ Variable } & \multicolumn{1}{c|}{ Standard error } & \multicolumn{1}{c|}{ t-Statistics } & \multicolumn{1}{c|}{ Probability } \\
\hline $\mathrm{EFF}_{2}$ & 188.4078 & 4.9908 & 0.0016 \\
\hline $\mathrm{EFF}_{2}(-1)$ & 169.1183 & -3.7263 & 0.0074 \\
\hline $\mathrm{CU}_{2}$ & 66279.7700 & 3.6254 & 0.0084 \\
\hline $\mathrm{AR}(3)$ & 0.4173 & -2.6616 & 0.0324 \\
\hline
\end{tabular}

Source: own calculations.

Table A3. Estimated quantities of marble quarries aggregates

\begin{tabular}{|l|r|r|r|}
\hline \multicolumn{1}{|c|}{ Variable } & \multicolumn{1}{c|}{ Standard error } & t-Statistics & \multicolumn{1}{c|}{ Probability } \\
\hline $\mathrm{FF}_{3}$ & 78.2359 & 25.4917 & 0.0000 \\
\hline $\mathrm{EFF}_{3}(-1)$ & 83.9756 & -18.7617 & 0.0000 \\
\hline $\mathrm{Q}_{3}(-2)$ & 0.0478 & 9.0264 & 0.0000 \\
\hline $\mathrm{AR}(2)$ & 0.1089 & -6.0276 & 0.0005 \\
\hline
\end{tabular}

Source: own calculations.

Table A4. Estimated quantities of derivatives

\begin{tabular}{|l|r|r|r|}
\hline \multicolumn{1}{|c|}{ Variable } & \multicolumn{1}{c|}{ Standard error } & \multicolumn{1}{c|}{ t-Statistics } & \multicolumn{1}{c|}{ Probability } \\
\hline $\mathrm{Q}_{4}(-1)$ & 0.0856 & 11.4595 & 0.0000 \\
\hline $\mathrm{Q}_{4}(-3)$ & 0.0915 & -2.9163 & 0.0171 \\
\hline $\mathrm{EFF}_{4}$ & 47.7630 & 2.0302 & 0.0729 \\
\hline
\end{tabular}

Source: own calculations. 
Table A5. Estimated staffing for marble and tiles

\begin{tabular}{|l|r|r|r|}
\hline \multicolumn{1}{|c|}{ Variable } & \multicolumn{1}{|c|}{ Standard error } & \multicolumn{1}{c|}{ t-Statistics } & \multicolumn{1}{c|}{ Probability } \\
\hline $\mathrm{CW}$ & 0.4566 & -3.6420 & 0.0039 \\
\hline $\mathrm{CW}(-1)$ & 0.5070 & 3.2084 & 0.0083 \\
\hline $\mathrm{EFF}_{1}(-1)$ & 0.0171 & 59.3975 & 0.0000 \\
\hline
\end{tabular}

Source: own calculations.

Table A6. Estimated staffing for slabs blocks

\begin{tabular}{|l|r|r|r|}
\hline \multicolumn{1}{|c|}{ Variable } & Standard error & t-Statistics & \multicolumn{1}{c|}{ Probability } \\
\hline $\mathrm{Q}_{2}$ & 0.0001 & 2.4297 & 0.0317 \\
\hline $\mathrm{CW}$ & 0.0991 & -8.6292 & 0.0000 \\
\hline $\mathrm{C}$ & 42.3790 & 11.2786 & 0.0000 \\
\hline
\end{tabular}

Source: own calculations.

Table A7. Estimated staffing for marble aggregates

\begin{tabular}{|l|r|r|r|}
\hline \multicolumn{1}{|c|}{ Variable } & Standard error & t-Statistics & \multicolumn{1}{c|}{ Probability } \\
\hline $\mathrm{CW}$ & 0.0260 & -1.9896 & 0.0778 \\
\hline $\mathrm{Q}_{3}(-1)$ & 00.0000 & 8.6569 & 0.0000 \\
\hline $\mathrm{EFF}_{3}(-2)$ & 0.0820 & 2.3733 & 0.0417 \\
\hline $\mathrm{C}$ & 15.4847 & 6.3395 & 0.0001 \\
\hline
\end{tabular}

Source: own calculations.

Table A8. Estimated staffing for quarries derivatives

\begin{tabular}{|l|r|r|r|}
\hline \multicolumn{1}{|c|}{ Variable } & \multicolumn{1}{c|}{ Standard error } & t-Statistics & \multicolumn{1}{c|}{ Probability } \\
\hline $\mathrm{CW}$ & 0.0124 & -2.1789 & 0.0500 \\
\hline $\mathrm{EFF}_{4}(-1)$ & 0.0207 & 47.3900 & 0.0000 \\
\hline
\end{tabular}

Source: own calculations.

Table A9. Estimated quantities sold of marble blocks

\begin{tabular}{|l|r|r|r|}
\hline \multicolumn{1}{|c|}{ Variable } & Standard error & t-Statistics & \multicolumn{1}{c|}{ Probability } \\
\hline $\mathrm{Q}_{1}$ & 0.0037 & 10.9136 & 0.0083 \\
\hline $\mathrm{QV}_{1}(-2)$ & 0.0393 & -14.9288 & 0.0045 \\
\hline $\mathrm{QV}_{1}(-3)$ & 0.0282 & -16.1884 & 0.0038 \\
\hline $\mathrm{P}_{1}$ & 25.1246 & -2.6271 & 0.1195 \\
\hline $\mathrm{D}_{1}$ & 0.0171 & 11.8782 & 0.0070 \\
\hline $\mathrm{C}$ & 671.6772 & 10.6732 & 0.0087 \\
\hline $\mathrm{AR}(1)$ & 0.2235 & -7.1542 & 0.0190 \\
\hline $\mathrm{AR}(2)$ & 0.3241 & -4.0139 & 0.0568 \\
\hline
\end{tabular}

Source: own calculations.

Table A10. Estimated quantities sold of slabs and tiles

\begin{tabular}{|l|r|r|r|}
\hline Variable & Standard error & t-Statistics & Probability \\
\hline $\mathrm{Q}_{2}$ & 0.0428 & 8.5866 & 0.0004 \\
\hline $\mathrm{D}_{2}$ & 0.0378 & 4.2307 & 0.0082 \\
\hline
\end{tabular}




\begin{tabular}{|l|r|r|r|}
\hline $\mathrm{P}_{2}$ & 21965.7100 & -6.1664 & 0.0016 \\
\hline $\mathrm{P}_{2}(-1)$ & 23943.9100 & 5.9676 & 0.0019 \\
\hline $\mathrm{QV}_{2}(-1)$ & 0.0552 & 6.1958 & 0.0016 \\
\hline $\mathrm{AR}(1)$ & 0.2179 & -4.3534 & 0.0073 \\
\hline $\mathrm{AR}(2)$ & 0.1883 & -3.6664 & 0.0145 \\
\hline
\end{tabular}

Source: own calculations.

Table A11. Estimated quantities sold of derivatives of marble

\begin{tabular}{|l|r|r|r|}
\hline \multicolumn{1}{|c|}{ Variable } & \multicolumn{1}{c|}{ Standard error } & t-Statistics & Probability \\
\hline $\mathrm{Q}_{3}$ & 0.0198 & 50.2150 & 0.0000 \\
\hline $\mathrm{P}_{3}$ & 2080.1980 & -2.1519 & 0.0978 \\
\hline $\mathrm{QV}_{3}(-2)$ & 0.0207 & 2.3662 & 0.0771 \\
\hline $\mathrm{C}$ & 3934.4120 & 2.0031 & 0.1157 \\
\hline $\mathrm{AR}(4)$ & 0.1187 & -6.6031 & 0.0027 \\
\hline
\end{tabular}

Source: own calculations.

Table A12. Estimated quantities sold of quarries aggregates

\begin{tabular}{|l|r|r|r|}
\hline \multicolumn{1}{|c|}{ Variable } & Standard error & t-Statistics & \multicolumn{1}{c|}{ Probability } \\
\hline $\mathrm{Q}_{4}$ & 0.0635 & 17.0713 & 0.0000 \\
\hline $\mathrm{Q}_{4}(-2)$ & 0.2715 & -2.8730 & 0.0166 \\
\hline $\mathrm{QV}_{4}(-2)$ & 0.2635 & 2.7605 & 0.0201 \\
\hline
\end{tabular}

Source: own calculations. 